\title{
Editorial
}

\section{Editorial da Revista Ensaio 49}

A Revista Ensaio: Avaliação e Políticas Públicas em Educação, em seu quadragésimo nono número, se apresenta trazendo uma valiosa contribuição aos estudiosos e interessados em Avaliação, nos seus múltiplos enfoques, considerando-se a diversidade presente nas abordagens feitas pelos autores dos textos que compõem este exemplar.

É importante destacar-se que, mesmo tratando de temática diferenciada, cada artigo traduz a preocupação e o compromisso de seu autor, no sentido de ampliar, aprofundar e mesmo provocar questionamentos, à luz de tudo que se conhece de Avaliação e Políticas Públicas em Educação. Os artigos, ora publicados, retratam os principais focos de interesses destes pesquisadores, contribuindo, sobremaneira, para o avanço nos conhecimentos e para a disseminação das informações de área tão importante, complexa e atual como a área de Avaliação.

Alberto de Mello e Souza, no artigo Determinantes da aprendizagem em escolas municipais, enfoca a questão da escola eficiente, procurando examinar, em escolas situadas em três municípios, os fatores que mais influenciam na aprendizagem dos alunos. Os dados analisados nesta pesquisa têm origem em um teste clássico de Língua Portuguesa, aplicados a alunos da quarta série de turmas e escolas selecionadas, como também em questionários sobre os alunos, professores e diretores dessas escolas.

Partindo de um registro sociológico e organizacional, Leonor Lima Torres, no artigo Cultura organizacional no contexto escolar: o regresso à escola como desafio na reconstrução de um modelo teórico, busca discutir as possibilidades heurísticas da problemática da cultura organizacional para a compreensão do funcionamento cotidiano das organizações escolares.

A questão das cotas, com vistas ao ingresso no Ensino Superior, é abordada no artigo Acesso à universidade pública através de cotas: uma reflexão a partir da percepção dos alunos de um pré-vestibular inclusivo, da autoria de Simão Dias Vasconcelos e Ednaldo Gomes da Silva, no qual seus autores, através de pesquisa, procuram levantar a percepção dos alunos de um pré-vestibular inclusivo sobre a implantação das cotas, bem como outras informações sobre este tema bastante controvertido e atual.

O emprego das inovações tecnológicas e a formação do professor são discutidos por Alda Maria Duarte Araújo Castro no artigo Mudanças tecnológicas e suas implicações na política de formação do professor, que enfoca, especialmente, a influência de novas tecnologias na Política de Formação de Professores da Educação Básica, tendo 
como referência a Legislação Educacional que trata deste assunto, onde é evidenciada a necessidade de mudanças nesta Área com vistas ao seu ajuste às necessidades atuais .

Na sessão Página Aberta, o texto de Antonio Elísio Pazeto intitulado a Universidade, formação e mundo do trabalho: superando a visão corporativa, versa sobre este tema complexo, particularmente em tempos de mudanças estruturais, como os vividos atualmente.Ao centro deste debate, encontra-se a Universidade no desempenho de seus múltiplos papéis.

A Pesquisa em Síntese apresenta a Auto-avaliação psicossocial de professores, trabalho realizado por Edson A de Souza Filho com o objetivo de verificar a conexão existente entre a adoção de critérios psicossociais de escolha da profissão de professor e formas do exercício da mesma. Esta pesquisa envolveu professores do Ensino Fundamental privado e público, como também professores do Ensino Universitário público, todos da cidade do Rio de Janeiro.

Em Informes e Participações, Agustín Navarra, com a colaboração de Cláudio de Moura Castro,Leno S. Pedrotti e Júlio K. Inafuco, no texto Capacitação de professores em matemática contextualizada: projeto bem-sucedido no Brasil, apresenta uma resenha de um Projeto desenvolvido pelo CORD - Center for Ocupacional Research and Developement, Waco, Texas,EUA - para a capacitação de professores de Matemática do Ensino Médio da rede pública do Estado do Paraná no Brasil. Esta capacitação teve como objetivo atualizar a prática pedagógica e melhorar a eficácia dos professores nela envolvidos, através da exploração de metodologias contextualizadas.

Ainda nesta sessão, Ângela Cristina Dannemann, Thereza Penna Firme e Ana Carolina Letichevsky, no texto Estabelecendo a rede brasileira de avaliação: um trabaTho desafiador sem limites, trazem uma síntese do trabalho, de relevada importância, por elas apresentado na Joint Conference of the Canadian Evaluation Society and American Evaluation Association "Crossing Borders, Crossing Boundaries", Toronto, Canadá,em outubro de 2005. Este trabalho levou em consideração aspectos culturais e históricos, presentes em qualquer processo avaliativo, limitando discussões e estabelecendo fronteiras entre as diferentes instâncias, refletindo sobre a forma e como aqueles que utilizam a avaliação vêm contornando limites e ultrapassando fronteiras.

Deste modo, reafirma-se que a diversidade presente na Avaliação, tema central de nossa revista, fica, mais uma vez, evidenciada, não só pelas formas como os diferentes articulistas e colaboradores a enfocam, mas também pela gama de conclusões e questionamentos, certamente instigados a partir de sua leitura.

Carlos Alberto Serpa de Oliveira 